\title{
10 \\ Part-time farming trends in China
}

\section{Zhang Yue Zhou, Daniel A. Sumner and Hyunok Lee}

Since the Chinese government instituted a strict policy restricting rural labour movement in the early 1960s, a huge labour force has been retained in agriculture. Currently, the labour force that is in excess of farming requirements is estimated in the order of over 200 million. To sustain China's economic development, it is argued that this labour force needs to be absorbed into nonfarming activities (Zhou et al. 1992; Johnson 1999).

Broadly, there are two major paths through which labour can be shifted out of farming activities: leaving the farm completely and moving to other industries; or remaining farm-based and where possible engaging in non-farming activities. The latter has often been referred to as part-time farming. While any large-scale relocation of farm labour may not be expected in the near future, there is already an emerging trend towards part-time farming.

Hence, an understanding of the development of part-time farming in China would be invaluable for both academic inquiry and policy formulation. Unfortunately, despite the fact that there is a rich literature that addresses the agricultural labour issue in general, studies that examine the part-time farming issue in China remain scarce. A few such examples include Yang and Cai (1991), Tian and Shi (1991), Ye (1992), and Zhang et al. (1996).

Yang and Cai (1991) suggest a model of decision making on part-time farming behaviour and examine factors that affect part-time farming behaviour using macro-level data. Tian and Shi (1991) offer a broad discussion on the social and economic background of part-time transfer of agricultural labour and the relationships between part-time transfer, industrialisation, urbanisation and agricultural development. They point out that part-time transfer can be used as a practical choice for transferring agricultural labour in China.

Using cross-sectional farm survey data, Zhang et al. (1996) describe the part-time farming situation and the impact of part-time farming on farm 


\section{Part-time farming trends in China}

households in ten provinces in 1994. Using 1986 survey data, Wan (1995) assesses rural-rural, rural-urban and urban-rural migration in China. Rozelle et al. (1999) examine rural-urban migration using cross-sectional data collected in 1996 from eight provinces in China.

Few have attempted to empirically assess the historical trend of part-time farming in China. This study, using ten-year farm-level survey data, examines the development of part-time farming in China. The two key research questions we attempt to answer are how part-time farming evolves over time and whether part-time farming may be related to regional economic development.

\section{Factors affecting part-time farming}

Part-time farming can be found in many countries (see Jussaume 1991; Loyns and Kraut 1992; Tweeten et al. 1993; Ali 1995; Weiss 1997). Part-time farming is an important way for farmers to divert family labour to nonfarming activities. There are some major factors that affect the allocation of on-farm and off-farm labour. ${ }^{1}$

\section{Technical change}

Capital input using technical change will substitute capital with labour. The output effect induced by the increase in the marginal product of labour input would positively affect the demand for labour but with a quasi-fixed input (in this case, land) the negative substitution effect will be greater. As a result, part-time transfer will take place when farmers try to utilise their labour best but cannot completely leave their farm due to farming needs.

\section{Land system}

In countries where land is equally distributed and land transfer is restricted, part-time farming will evolve.

\section{Relative return}

It is common that farming has a relatively lower return, as often observed in disparity of rural and urban incomes. The desire to obtain a higher return and maximise family income is an important force driving farmers to engage in non-farming activities.

\section{Traditional land ideology}

In some countries, farmers are so attached to their land that they do not want to give it up. Some perceive their land as security or family insurance where social security programs are lacking. This leads them to hold onto their land even if their non-farming income is very high. 


\section{Dilemmas of China's Growth in the Twenty-First Century}

\section{Urbanisation and industrialisation}

Rapid urbanisation and industrialisation mean a higher capacity to absorb agricultural labour.

\section{Dual social structure}

Where rural and urban areas are separated by administrative forces, there is little chance for agricultural labour to leave farming completely and be engaged in urban industrial activities. It can only take part in non-farming activities within rural areas.

In China, all of the above factors play a role in inducing the development of part-time farming, and indeed, there is already a trend towards part-time farming. While this trend has important implications in government policy formation, this issue has received little attention. This study attempts to fill this gap by using farm-level survey data to assess the status of part-time farming in China.

\section{Conceptual considerations and data}

\section{What is part-time farming?}

Part-time farming refers to 'the practice whereby a farm worker or farm family earns income from both agricultural and non-agricultural employment or selfemployment' (Jussaume 1991:3). Part-time farming is not unique to modern times or to developed nations. 'It is an option that agriculturally dependent households around the world have exercised for generations. Only the recognition of the importance of part-time farming is new' (Jussaume 1991:3). While there is consensus about the notion of part-time farming, the technical definition differs slightly by country. This chapter adopts the classification of part-time farming that has been used in Japan. The Organisation for Economic Cooperation and Development (OECD) also adopts Japan's classification of part-time farming (Krasovec 1982, cited in Jussaume 1991:48).

In Japan part-time farming is defined as 'very small farms and any farm in which one or more household members are engaged in jobs other than farming' (OECD 1995:14-15). More detailed classification includes (OECD 1995:11)

- Part-time farm household. Farming household which has one or more household members engaged in jobs other than farming and where they have been employed for 30 days or more, or engaged in their own non-farm business from which they have earned 100,000 yen in $1990(70,000$ yen in 1980) or more, during a year.

- Part-time farm household Type I: Farm household where less than 50 per cent of income was earned from non-farm jobs. 


\section{Part-time farming trends in China}

- Part-time farm household Type II: Farm household where more than 50 per cent of income was earned from non-farm jobs.

- Full-time farm household: Farm household which has no household member engaged in non-farm employment.

\section{Data}

Farm-level survey data are regularly collected by the Research Centre for Rural Economy (RCRE) of the Ministry of Agriculture in China. The survey first began in 1986 and was carried out annually except in 1992 and 1994. In each village, some 100 households were surveyed. The survey instruments have evolved over the years. Those used for 1986-91 were the same (with 312 variables) but they were expanded for the 1993 survey (with 394 variables) and further expanded for the 1995-97 surveys (with 439 variables). Data used in this study cover the period 1986-97.

For this study, three provinces representing the different stages of economic development are selected. They include Guangdong, which represents the most developed; Hubei, which represents medium development; and Yunnan, which represents the least developed. Three villages are then selected again from each province according to the level of economic development as measured by per capita income. Brief background information on the selected provinces and villages is presented in Table A10.1 (see Appendix 10.1).

In the farm household surveys by the RCRE, there are nine categories of major family business activities: (1) cropping, (2) forestry, (3) animal husbandry, (4) fishery, (5) industry, (6) construction, (7) transportation, (8) tertiary services, and (9) others. Since the rural economic reforms, farms have been allowed to diversify their farm activities in any of these categories.

In this study, activities belonging to categories $1-4$ are considered as farming and the rest as non-farming (categories 5-9). ${ }^{3}$ Detailed data on labour-days used for each of the nine business activities are available from the household survey. To ensure the accuracy of data, we used a number of variables to crosscheck the data. Whenever doubt arose about observation, that observation was eliminated.

\section{Empirical results}

Figure 10.1 shows the historical trend of part-time farming for the data combining all three provinces. Three observations stand out. First, for the period under examination, part-time farming (both Type I and Type II) is significant, at close to 50 per cent. Second, the majority of part-time farming households are Type II. Third, part-time farming peaked in 1993 and then began to slow. 


\section{Dilemmas of China's Growth in the Twenty-First Century}

The part-time farming trend broken down at the provincial level is shown in Figure 10.2. As expected, Guangdong province shows the highest parttiming farming trend, consistent with its economic development. This is also the region where the post 1993 downturn of part-time farming did not occur. Further, while the bulk of part-time farm households are Type II, the share of Type I part-time farm households has been steadily declining, reaching 2 per cent in 1997. In the economically least-developed Yunnan province, parttime farming development fluctuates most and has declined sharply (from 50 per cent in 1993 to 32 per cent in 1997). It also has a higher proportion of Type I part-time farm households. In the economically medium-developed Hubei province, the part-time farming level is below that of Yunnan, the economically least-developed region. This is due to the fact that one of the villages included in the analysis for Yunnan (Village 1) is in a wealthy area with a very high part-time farming level (Table 10.1).

When we examine the data at the village-level (Table 10.1), it is observed that in general, in economically more developed areas, such as all three villages in Guangdong province and in Yunnan's Village 1, part-time farming is taking place at a much higher level (50 per cent or higher) and is increasing. On the other hand, the level of part-time farming in medium or less-developed areas is accordingly lower. This indicates that the level of local economic development is an important factor for the emergence of part-time farming in a region. It is interesting to note that the poorest village (Village 2 in Yunnan) once had a very high part-time farming level (65 per cent in 1993) but dropped sharply

\section{Figure 10.1 Part-time farming trends in China (all three provinces)}

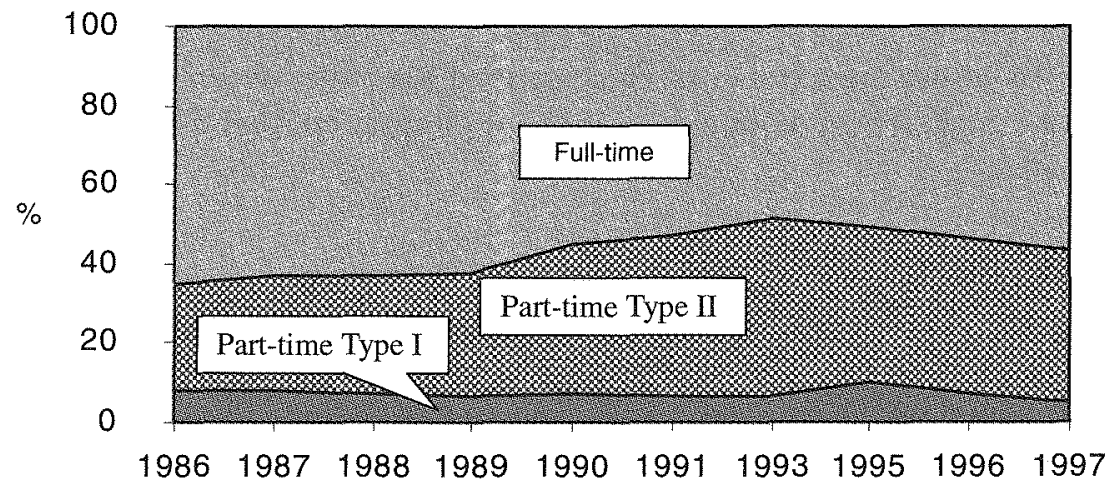

Source: Calculated from the survey data. 


\section{Part-time farming trends in China}

\section{Figure 10.2 Part-time farming trends at the provincial level}

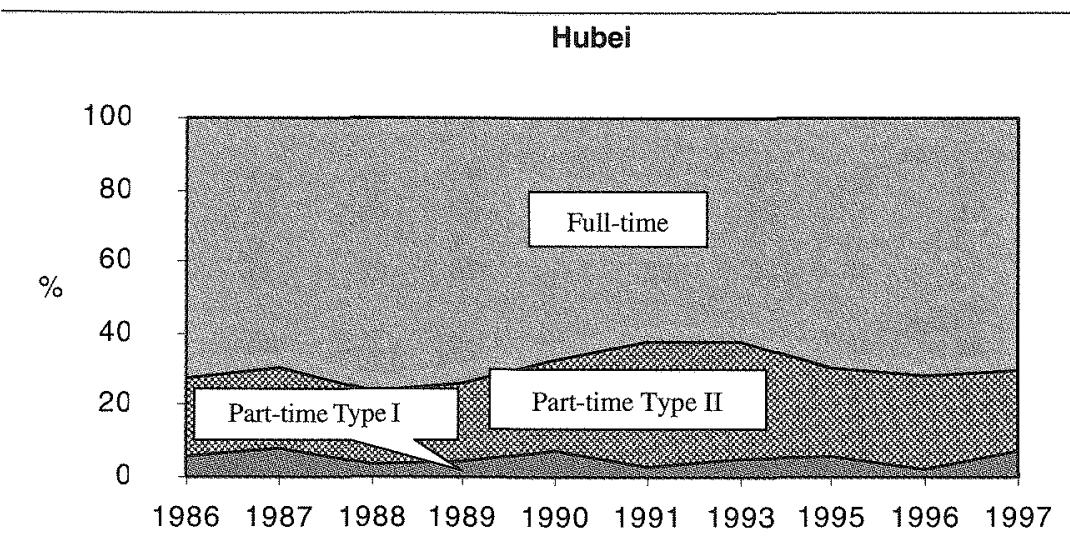

\section{Guangdong}
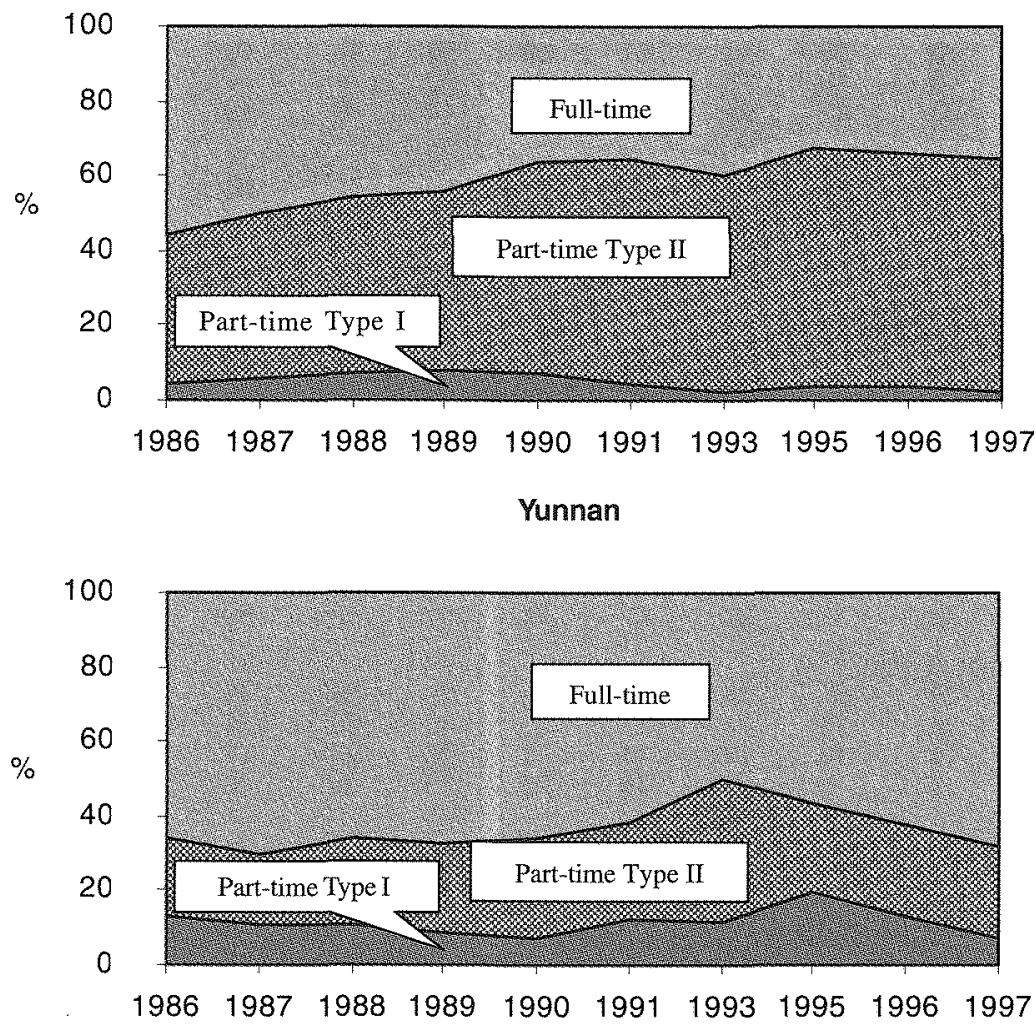

Source: Calculated from the survey data. 


\section{Dilemmas of China's Growth in the Twenty-First Century}

\section{Table 10.1 Part-time farming trends in China at the village level (1986-97)}

\begin{tabular}{|c|c|c|c|c|c|c|c|c|c|c|}
\hline & 1986 & 1987 & 1988 & 1989 & 1990 & 1991 & 1993 & 1995 & 1996 & 1997 \\
\hline $\begin{array}{l}\text { Hubei prov } \\
\text { Full-time } \\
\text { Part-time } \\
\text { Type ] } \\
\text { Type II }\end{array}$ & $\begin{array}{l}\text { Villag } \\
82 \\
18 \\
4 \\
14\end{array}$ & $\begin{array}{r}1 \\
83 \\
17 \\
1 \\
16\end{array}$ & $\begin{array}{r}76 \\
24 \\
4 \\
20\end{array}$ & $\begin{array}{r}77 \\
23 \\
1 \\
22\end{array}$ & $\begin{array}{l}. . \\
. . \\
. . \\
. .\end{array}$ & $\begin{array}{r}73 \\
27 \\
1 \\
26\end{array}$ & $\begin{array}{r}57 \\
43 \\
- \\
43\end{array}$ & $\begin{array}{r}62 \\
38 \\
4 \\
35\end{array}$ & $\begin{array}{r}78 \\
22 \\
2 \\
20\end{array}$ & $\begin{array}{r}75 \\
25 \\
6 \\
19\end{array}$ \\
\hline $\begin{array}{l}\text { Hubei prov } \\
\text { Full-time } \\
\text { Part-time } \\
\text { Type I } \\
\text { Type II }\end{array}$ & $\begin{array}{l}\text { Villag } \\
44 \\
56 \\
12 \\
45\end{array}$ & $\begin{array}{l}2 \\
41 \\
59 \\
13 \\
46\end{array}$ & $\begin{array}{r}58 \\
42 \\
4 \\
38\end{array}$ & $\begin{array}{l}50 \\
50 \\
10 \\
40\end{array}$ & $\begin{array}{l}49 \\
51 \\
12 \\
39\end{array}$ & $\begin{array}{r}27 \\
73 \\
4 \\
69\end{array}$ & $\begin{array}{l}45 \\
55 \\
12 \\
43\end{array}$ & $\begin{array}{r}69 \\
31 \\
5 \\
26\end{array}$ & $\begin{array}{r}63 \\
37 \\
2 \\
36\end{array}$ & $\begin{array}{r}56 \\
44 \\
8 \\
36\end{array}$ \\
\hline $\begin{array}{l}\text { Hubei prov } \\
\text { Full-time } \\
\text { Part-time } \\
\text { Type I } \\
\text { Type II }\end{array}$ & $\begin{array}{l}\text {, Villag } \\
93 \\
7 \\
2 \\
5\end{array}$ & $\begin{array}{r}3 \\
84 \\
16 \\
10 \\
6\end{array}$ & $\begin{array}{r}92 \\
8 \\
3 \\
6\end{array}$ & $\begin{array}{r}92 \\
8 \\
2 \\
7\end{array}$ & $\begin{array}{r}89 \\
11 \\
2 \\
9\end{array}$ & $\begin{array}{r}89 \\
11 \\
3 \\
8\end{array}$ & $\begin{array}{r}85 \\
15 \\
3 \\
12\end{array}$ & $\begin{array}{r}79 \\
21 \\
8 \\
13\end{array}$ & $\begin{array}{r}78 \\
22 \\
2 \\
20\end{array}$ & $\begin{array}{r}82 \\
18 \\
6 \\
12\end{array}$ \\
\hline $\begin{array}{l}\text { Guangdon } \\
\text { Full-time } \\
\text { Part-time } \\
\text { Type I } \\
\text { Type II }\end{array}$ & $\begin{array}{l}\text { ovince, } \\
70 \\
30 \\
8 \\
23\end{array}$ & $\begin{array}{l}\text { illage } \\
63 \\
38 \\
10 \\
27\end{array}$ & $\begin{array}{l}54 \\
46 \\
17 \\
29\end{array}$ & $\begin{array}{l}49 \\
51 \\
10 \\
41\end{array}$ & $\begin{array}{l}40 \\
60 \\
11 \\
49\end{array}$ & $\begin{array}{r}42 \\
58 \\
9 \\
49\end{array}$ & $\begin{array}{r}51 \\
49 \\
- \\
49\end{array}$ & $\begin{array}{r}51 \\
49 \\
49\end{array}$ & $\begin{array}{r}50 \\
50 \\
1 \\
49\end{array}$ & $\begin{array}{r}51 \\
49 \\
1 \\
48\end{array}$ \\
\hline $\begin{array}{l}\text { Guangdon } \\
\text { Full-time } \\
\text { Part-time } \\
\text { Type I } \\
\text { Type II }\end{array}$ & $\begin{array}{l}\text { ovince, } \\
42 \\
58 \\
3 \\
55\end{array}$ & $\begin{array}{l}\text { /illage: } \\
35 \\
65 \\
2 \\
63\end{array}$ & $\begin{array}{r}40 \\
60 \\
2 \\
57\end{array}$ & $\begin{array}{r}45 \\
55 \\
4 \\
51\end{array}$ & $\begin{array}{r}41 \\
59 \\
4 \\
55\end{array}$ & $\begin{array}{r}39 \\
61 \\
1 \\
60\end{array}$ & $\begin{array}{r}45 \\
55 \\
3 \\
52\end{array}$ & $\begin{array}{r}34 \\
66 \\
4 \\
62\end{array}$ & $\begin{array}{r}35 \\
65 \\
7 \\
58\end{array}$ & $\begin{array}{r}46 \\
54 \\
3 \\
51\end{array}$ \\
\hline $\begin{array}{l}\text { Guangdon } \\
\text { Full-time } \\
\text { Part-time } \\
\text { Type I } \\
\text { Type II }\end{array}$ & $\begin{array}{l}\text { ovince, } \\
58 \\
42 \\
2 \\
39\end{array}$ & $\begin{array}{c}\text { iillage } \\
54 \\
46 \\
5 \\
41\end{array}$ & $\begin{array}{r}43 \\
57 \\
3 \\
53\end{array}$ & $\begin{array}{r}38 \\
62 \\
9 \\
53\end{array}$ & $\begin{array}{r}28 \\
72 \\
6 \\
66\end{array}$ & $\begin{array}{r}26 \\
74 \\
2 \\
72\end{array}$ & $\begin{array}{r}24 \\
76 \\
3 \\
73\end{array}$ & $\begin{array}{r}13 \\
87 \\
7 \\
80\end{array}$ & $\begin{array}{r}16 \\
84 \\
4 \\
80\end{array}$ & $\begin{array}{r}10 \\
90 \\
2 \\
87\end{array}$ \\
\hline $\begin{array}{l}\text { Yunnan pro } \\
\text { Full-time } \\
\text { Part-time } \\
\text { Type I } \\
\text { Type II }\end{array}$ & $\begin{array}{l}c e, \text { Villa } \\
50 \\
50 \\
7 \\
43\end{array}$ & $\begin{array}{r}1 \\
57 \\
43 \\
6 \\
37\end{array}$ & $\begin{array}{r}41 \\
59 \\
6 \\
53\end{array}$ & $\begin{array}{r}49 \\
51 \\
4 \\
47\end{array}$ & $\begin{array}{r}46 \\
54 \\
4 \\
51\end{array}$ & $\begin{array}{r}48 \\
53 \\
1 \\
51\end{array}$ & $\begin{array}{r}38 \\
62 \\
62\end{array}$ & $\begin{array}{r}41 \\
59 \\
59\end{array}$ & $\begin{array}{r}43 \\
57 \\
1 \\
56\end{array}$ & $\begin{array}{r}35 \\
65 \\
4 \\
61\end{array}$ \\
\hline $\begin{array}{l}\text { Yunnan pro } \\
\text { Full-time } \\
\text { Part-time } \\
\text { Type I } \\
\text { Type II }\end{array}$ & $\begin{array}{l}\text { ce, Villa } \\
79 \\
21 \\
14 \\
7\end{array}$ & $\begin{array}{r}1 e 2 \\
85 \\
15 \\
10 \\
5\end{array}$ & $\begin{array}{r}78 \\
22 \\
14 \\
8\end{array}$ & $\begin{array}{l}73 \\
27 \\
11 \\
16\end{array}$ & $\begin{array}{l}67 \\
33 \\
11 \\
21\end{array}$ & $\begin{array}{l}55 \\
45 \\
26 \\
19\end{array}$ & $\begin{array}{l}35 \\
65 \\
22 \\
43\end{array}$ & $\begin{array}{l}49 \\
51 \\
41 \\
10\end{array}$ & $\begin{array}{r}61 \\
39 \\
31 \\
8\end{array}$ & $\begin{array}{r}83 \\
17 \\
14 \\
3\end{array}$ \\
\hline $\begin{array}{l}\text { Yunnan pro } \\
\text { Full-time } \\
\text { Part-time } \\
\text { Type I } \\
\text { Type II }\end{array}$ & $\begin{array}{l}\text { ce, Villa } \\
65 \\
35 \\
17 \\
17\end{array}$ & $\begin{array}{l}3 \\
67 \\
33 \\
15 \\
18\end{array}$ & $\begin{array}{l}74 \\
26 \\
13 \\
14\end{array}$ & $\begin{array}{r}75 \\
25 \\
9 \\
16\end{array}$ & $\begin{array}{r}84 \\
16 \\
7 \\
10\end{array}$ & $\begin{array}{r}80 \\
20 \\
8 \\
12\end{array}$ & $\begin{array}{l}76 \\
24 \\
13 \\
11\end{array}$ & $\begin{array}{r}78 \\
22 \\
14 \\
8\end{array}$ & $\begin{array}{r}80 \\
20 \\
4 \\
15\end{array}$ & $\begin{array}{r}84 \\
16 \\
4 \\
12\end{array}$ \\
\hline
\end{tabular}

Source: Calculated from the farm survey data. 


\section{Part-time farming trends in China}

in recent years (17 per cent in 1997). This phenomenon may have been dictated by the availability of non-farm employment. It is possible that many farmers from this poor village look for employment opportunities outside farming. Therefore, their non-farm activities also fluctuate with outside opportunities. This is consistent with the situation that prevailed in China during that time period.

In the early 1990s, there were increased numbers of farmers who travelled around the country to look for employment opportunities and there were abundant reports about this trend (see for example, Chen and Xu 1993; Zhu 1993; Wang 1994; Research Group 1995). As reflected in the results from this study (Figure 10.1), part-time farming level increased and peaked in 1993. Then, as urban economic reforms went further, employment for urban dwellers became a problem. Many city governments imposed restrictions on employment for rural labourers (Cai and Chan 2000). Soon many of the rural labourers had to return to their land and part-time farming declined (Figure 10.1). The reverse may also be true; reduced restrictions on farmers' employment in urban areas would result in increases in part-time farming. It is likely that government policy has an important bearing on the rise and fall of part-time farming, particularly in the case of Village 2 of Yunnan.

In addition to the level of local economic development and government policy, there are a number of other factors that affect the development of parttime farming, such as per capita arable land (Figure 10.3). The average landholding over the three-provinces is about one $\mathrm{mu}$ (1/15 hectare).

\section{Figure 10.3 Per capita arable land (mu)}

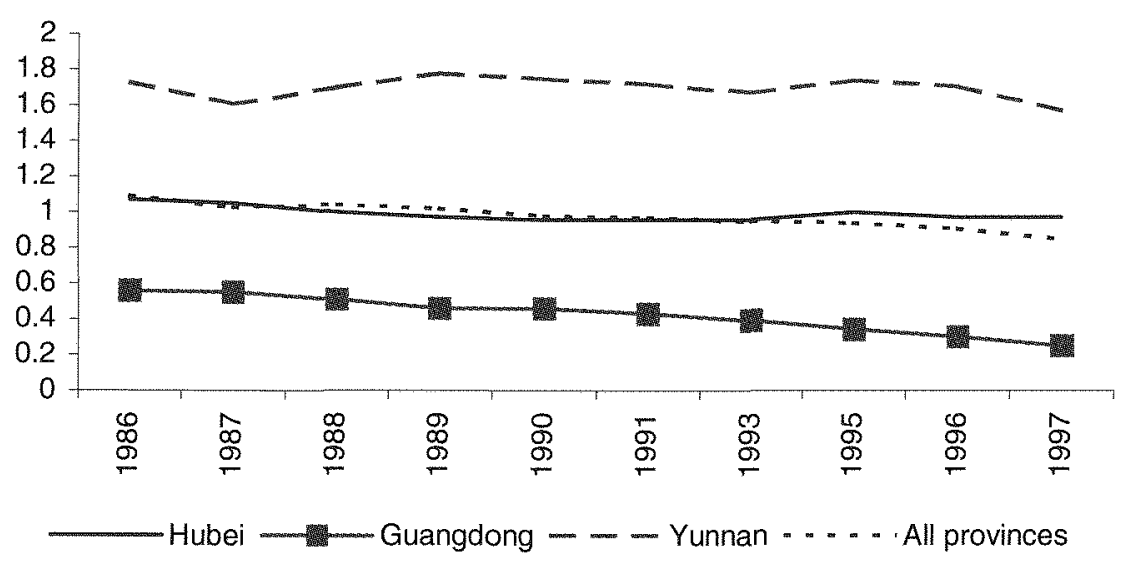

Source: Calculated from the survey data. 


\section{Dilemmas of China's Growth in the Twenty-First Century}

Guangdong's higher level of part-time farming is in part related to the low per capita arable land. Figure 10.3 shows that per capita arable land has declined over time; faster in more developed regions. If this trend continues, we will observe growth of part-time farming.

Figure 10.4 presents the ratio of non-farm earnings to farm earnings per labour-day. In all provinces and years studied, non-farm earnings have been higher than farm earnings. This encourages employment away from the farm. Note that this ratio was greatest in 1993 and the part-time farming level peaked during the same year (Figure 10.1). Johnson (1999) noted that ' $[t]$ he margin between the return to farm and nonfarm labour must be large enough to induce a rapid transfer to nonfarm jobs'. The results from this study tend to support Johnson's proposition. Figure 10.4 indicates that while the provinces differ in ratio by some margin these differences became pronounced in 1993. It is interesting to note that these differences are more distinct at the village level (Table A10.2). However, comparing Table A10.2 with the part-time trend at the village level (Table 10.1), it is not clear that higher part-time farming is always related to higher income ratios.

Besides these exogenous factors such as earning ratios, part-time farm decisions are also affected by the individual's qualification (suitability) and transactions costs. Whether an individual can start up his non-farming activities,

\section{Figure 10.4 Ratio of per labour-day income between non-farming and farming employment}

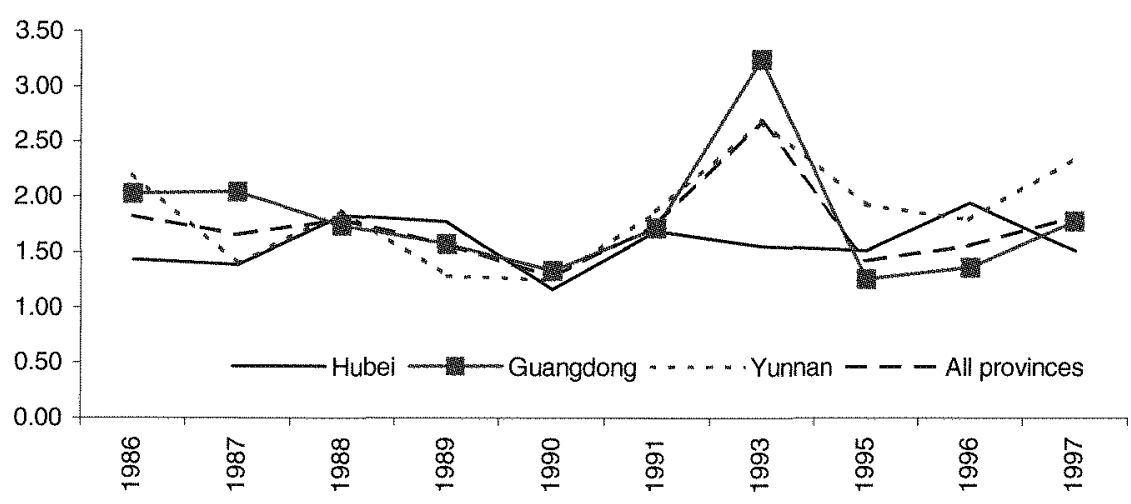

Source: Calculated from the survey data. 


\section{Part-time farming trends in China}

\section{Figure 10.5 Per family expenditure on cultural items (yuan/year)}

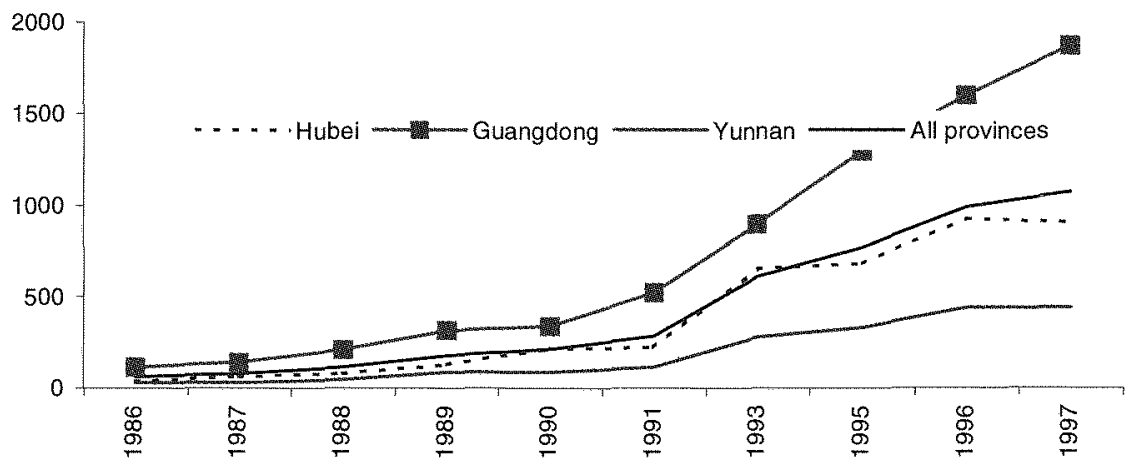

Source: Calculated from the survey data.

Figure 10.6 Number of radios/recorders owned per family

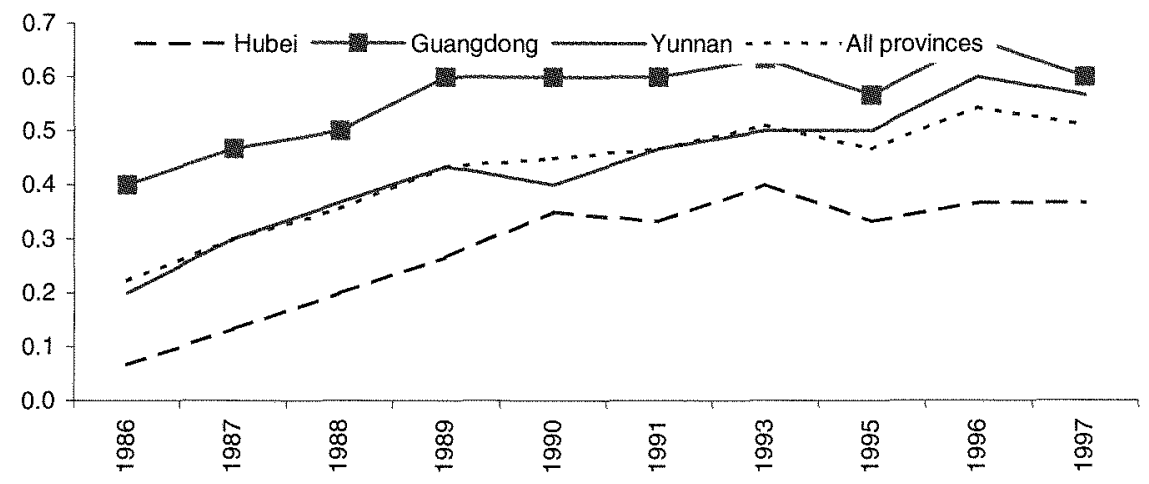

Source: Calculated from the survey data. 


\section{Dilemmas of China's Growth in the Twenty-First Century}

\section{Figure 10.7 Number of TVs owned per family}

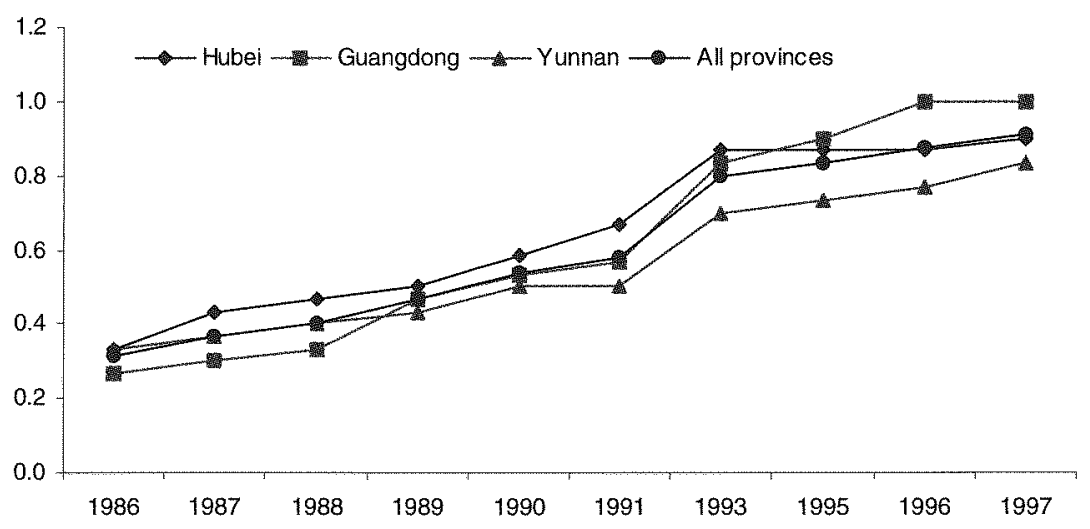

Source: calculated from the survey data.

\section{Figure 10.8 Percentage of illiterate or semi-illiterate rural labourers}

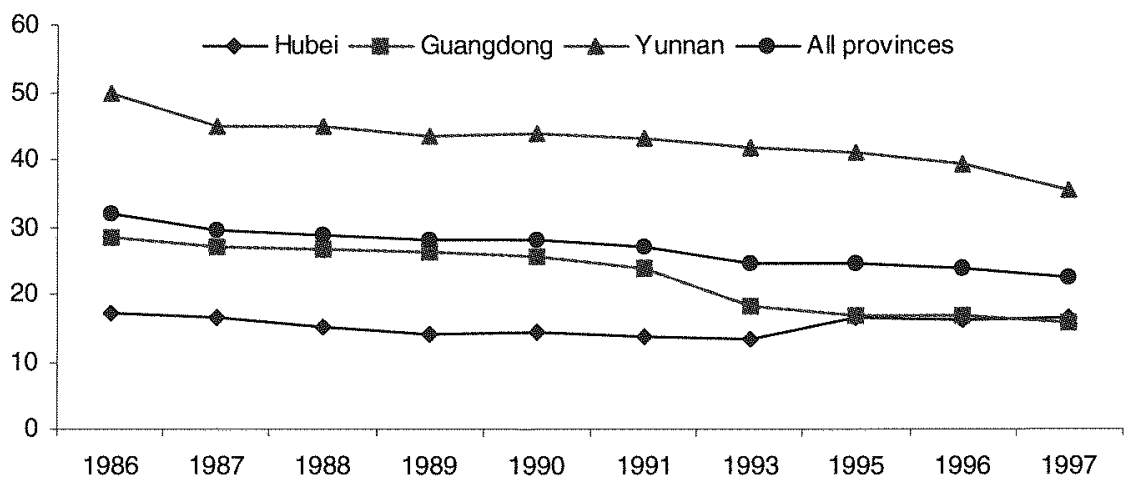

Source: Calculated from the survey data. 


\section{Part-time farming trends in China}

Table 10.2 Education of rural labourers at the village level

(1986-97)

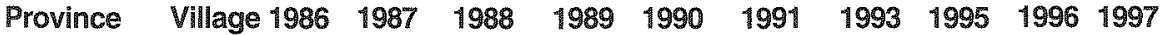
Illiterate and semi-illiterate rural labourers (\%)

\begin{tabular}{lrrrrrrrrrrr}
\multirow{4}{*}{ Hubei } & 1 & 12 & 10 & 11 & 9 & 10 & 11 & 11 & 8 & 6 & 10 \\
& 2 & 25 & 25 & 22 & 22 & 20 & 20 & 12 & 18 & 18 & 16 \\
& 3 & 15 & 14 & 12 & 11 & 13 & 10 & 17 & 23 & 24 & 23 \\
Guangdong & 1 & 10 & 10 & 11 & 13 & 13 & 11 & 5 & 4 & 3 & 3 \\
& 2 & 40 & 38 & 37 & 36 & 34 & 34 & 24 & 25 & 29 & 28 \\
\multirow{4}{*}{ Yunnan } & 3 & 35 & 33 & 32 & 30 & 30 & 27 & 26 & 21 & 18 & 16 \\
& 1 & 16 & 14 & 11 & 14 & 12 & 11 & 10 & 13 & 9 & 9 \\
& 2 & 90 & 92 & 89 & 87 & 88 & 87 & 85 & 84 & 85 & 81 \\
& 3 & 43 & 29 & 35 & 30 & 32 & 31 & 30 & 26 & 24 & 16
\end{tabular}

Rural labourers who completed primary school (\%)

\begin{tabular}{llllllllllll}
\multirow{4}{*}{ Hubei } & 1 & 47 & 48 & 44 & 47 & 45 & 43 & 42 & 43 & 47 & 47 \\
& 2 & 32 & 31 & 31 & 33 & 32 & 33 & 30 & 34 & 30 & 32 \\
& 3 & 44 & 43 & 45 & 43 & 47 & 51 & 45 & 39 & 35 & 38 \\
\multirow{5}{*}{ Guangdong } & 1 & 65 & 66 & 65 & 63 & 61 & 58 & 61 & 60 & 56 & 52 \\
& 2 & 33 & 35 & 36 & 37 & 36 & 36 & 39 & 41 & 37 & 40 \\
\multirow{4}{*}{ Yunnan } & 3 & 34 & 37 & 39 & 40 & 38 & 38 & 39 & 41 & 42 & 43 \\
& 1 & 56 & 55 & 55 & 53 & 56 & 56 & 49 & 46 & 49 & 47 \\
& 2 & 9 & 7 & 10 & 10 & 10 & 10 & 14 & 13 & 13 & 17 \\
& 3 & 35 & 47 & 45 & 48 & 47 & 46 & 45 & 50 & 50 & 58
\end{tabular}

Rural labourers who completed junior high school (\%)

\begin{tabular}{lrrrrrrrrrrr}
\multirow{4}{*}{ Hubei } & 1 & 31 & 32 & 33 & 32 & 33 & 33 & 41 & 43 & 41 & 37 \\
& 2 & 32 & 33 & 35 & 33 & 37 & 36 & 49 & 40 & 43 & 41 \\
\multirow{5}{*}{ Guangdong } & 3 & 34 & 37 & 36 & 40 & 37 & 35 & 33 & 33 & 36 & 35 \\
& 1 & 21 & 22 & 22 & 22 & 24 & 26 & 28 & 29 & 35 & 37 \\
& 2 & 23 & 24 & 24 & 25 & 25 & 26 & 30 & 28 & 28 & 26 \\
\multirow{4}{*}{ Yunnan } & 3 & 25 & 25 & 23 & 24 & 26 & 28 & 29 & 30 & 32 & 30 \\
& 1 & 27 & 27 & 30 & 29 & 27 & 28 & 37 & 36 & 33 & 35 \\
& 2 & 1 & 1 & 2 & 2 & 2 & 3 & 1 & 2 & 2 & 2 \\
& 3 & 20 & 23 & 18 & 20 & 19 & 21 & 23 & 23 & 25 & 24
\end{tabular}

Rural labourers who completed senior high school or above (\%)

\begin{tabular}{lrrrrrrrrrrr}
\multirow{4}{*}{ Hubei } & 1 & 10 & 9 & 12 & 12 & 13 & 13 & 6 & 6 & 6 & 6 \\
& 2 & 11 & 11 & 12 & 12 & 11 & 11 & 9 & 8 & 8 & 11 \\
\multirow{5}{*}{ Guangdong } & 3 & 7 & 6 & 6 & 6 & 3 & 3 & 5 & 5 & 4 & 4 \\
\multirow{3}{*}{ Yunnan } & 1 & 3 & 1 & 2 & 3 & 3 & 5 & 7 & 7 & 7 & 8 \\
& 3 & 4 & 4 & 3 & 3 & 4 & 4 & 7 & 5 & 6 & 6 \\
& 1 & 6 & 6 & 6 & 7 & 6 & 7 & 7 & 8 & 8 & 12 \\
& 2 & 3 & 3 & 4 & 5 & 5 & 5 & 3 & 5 & 8 & 8 \\
& 3 & $\ddot{2}$ & $\ddot{2}$ & $\ddot{2}$ & $\ddot{2}$ & $\ddot{2}$ & $\ddot{2}$ & $\ddot{2}$ & $\ddot{1}$ & $\ddot{1}$ & $\ddot{2}$
\end{tabular}

Source: Calculated from the farm survey data. 


\section{Dilemmas of China's Growth in the Twenty-First Century}

whether he knows which non-farming activities to work on, and can market his non-farm products (or equivalently, if looking for a job elsewhere, whether he goes beyond the village to look for a job, knows where to look for a job, and is offered a job), depends on his education level, labouring skills and ability to obtain information. Figures 10.5-10.8 show that in Guangdong, there is a higher family expenditure on media items, radios, recorders and TVs with a lower percentage of rural labourers who are illiterate or semi-illiterate. The percentage of rural labourers who completed senior high school or above is also highest (Table 10.2). This indicates that rural labourers in Guangdong are likely to be better informed about the opportunities of local non-farm work, which is consistent with high part-time farming in Guangdong.

Besides TVs and radios, telephones and computers play an important role in obtaining information. Ownership of telephones by rural households was not recorded in the survey until 1993 and the ownership of computers was not recorded until 1997. As expected, the ownership of telephones and computers is higher in more economically affluent provinces. Village 3 in Guangdong has a high level of computer ownership (Table 10.3). Interestingly, it is in this village that the part-time farming level has increased most (Table 10.1).

It is noted that in Village 2 of Yunnan, the percentage of illiterate and semi-illiterate rural labourers is very high ( 92 per cent in 1987 and 81 per cent in 1997) and the proportion who completed junior high school or above is very low ( 2 per cent in 1997) (Table 10.2). Yet the part-time farming level

\section{Table 10.3 Possession of telephones and computers at the village level}

\begin{tabular}{|c|c|c|c|c|c|c|c|c|c|}
\hline & & Hube & & & angd & ng & & unnar & \\
\hline & Vil 1 & Vil 2 & Vil 3 & Vil1 & Vil 2 & Vil 3 & Vil 1 & Vil 2 & Vill 3 \\
\hline \multicolumn{10}{|l|}{ Telephone } \\
\hline No. of households & 60 & 60 & 60 & 100 & 100 & 100 & 100 & 100 & 100 \\
\hline No. of telephones & 1 & & 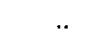 & 31 & 2 & 11 & 15 & .. & .. \\
\hline Average per household & 0.02 & .. & .. & 0.31 & 0.02 & 0.11 & 0.15 & .. & .. \\
\hline \multicolumn{10}{|l|}{1997} \\
\hline $\begin{array}{l}\text { No. of households } \\
\text { No. of telephones }\end{array}$ & $\begin{array}{l}60 \\
10\end{array}$ & 60 & 60 & 100 & 80 & 100 & 100 & 100 & 100 \\
\hline Average per household & 0.30 & 0.15 & $\begin{array}{r}5 \\
0.08\end{array}$ & 0.97 & 0.09 & 0.33 & 0.54 & $\begin{array}{l}. . \\
.\end{array}$ &. \\
\hline \multicolumn{10}{|l|}{$\begin{array}{l}\text { Computer } \\
1997\end{array}$} \\
\hline No. of households & 60 & 60 & 60 & 100 & 80 & 100 & 100 & 100 & 100 \\
\hline No. of computers & &. & & 3 & .. & 20 & .. & .. & .. \\
\hline Average per household & .. & .. & .. & 0.03 & .. & 0.20 & .. & .. & .. \\
\hline
\end{tabular}

Source: Calculated from the farm survey data. 


\section{Part-time farming trends in China}

was relatively higher, especially since the early 1990s (Table 10.1). It reached 65 per cent in 1993 but dropped sharply to 17 per cent in 1997. Table A10.3 shows that non-farm earnings by part-time households from this village are much lower compared to other villages.

It is likely that for farmers to take part in non-farm activities, they must have the internal desire, the intellectual and financial abilities, and there must be external opportunities for them to do so. This indicates that farmers' intellectual and financial abilities are crucial. These enable farmers to gather and digest information, to have the courage to look for non-farming job opportunities and to have the minimal labouring skills to be engaged or employed in non-farm work. Local economic development status, conditions of infrastructure, availability of markets for non-farm products, and government policies are important external factors. Not all of these external factors were addressed in this study due to the lack of data. Nonetheless, local economic development and the policy environment are two important factors affecting part-time farming development.

\section{Concluding remarks}

In this chapter we have assessed the status of part-time farming in China using farm-level survey data. Our findings indicate that part-time farming is significant in the regions of China examined. Overall, part-time farming was increasing over the period 1986-97. It peaked in 1993 but has slowed since then. Parttime farm households now account for more than 40 per cent of total farm households in the studied regions.

It seems that the level of local economic development is a major factor in the development of part-time farming in a region. In economically moredeveloped regions, part-timing farming is developing fast and is at a much higher level. In economically less-developed regions, part-time farming development is relatively slow and its growth inconsistent.

Government policy also has an important bearing on the development of part-time farming in China. With reduced restrictions on farmers' employment in non-farming activities or in urban areas, part-time farming increases; otherwise, many farm labourers have to return to or stay on their land. Other major factors that affect the development of part-time farming in China include the very small per capita arable land, income differences between farming and non-farming employment, farmers' education level and labouring skills and their ability to obtain and digest information.

The development of part-time farming in our data for China seems to have halted since the mid 1990s, especially in the poor areas. It has been widely recognised that this phenomenon is related to the sluggish market in recent years. However, following other countries' examples, there will be a further 


\section{Dilemmas of China's Growth in the Twenty-First Century}

shift in the labour force from farming to non-farming. How to make this shift is an important area that calls for further investigation. Given the relatively more important role of public policy in China, this transition can be significantly aided by prudent policy planning.

Future policy can be directed towards carrying out needed institutional reforms, especially removing restrictions on rural employment in the urban areas. Carefully conceived policy measures are needed to increase the opportunities of non-farm employment for rural people within the rural areas. Such policy measures will help China to alleviate or avoid over-concentration of industrialisation and population and other associated social problems as occurred in Japan in the 1970s and in Korea in the 1980s. The availability and improvement of basic infrastructure in rural areas (such as roads, water, electricity and telecommunication facilities) is also essential.

Part-time farming is a complex issue. This present study is only a modest attempt to address a very small number of questions. Many more questions remain to be explored.

- To what extent has traditional land ideology affected the development of part-time farming in China?

- How fast is China's part-time farming likely to develop in the near future?

- How has part-time farming affected farmers' income in China?

- How has part-time farming development affected the life of rural people and rural community development?

- How has part-time farming affected agricultural production and how will it affect agricultural production in the future?

- What are the likely impacts of part-time farming on the preservation of rural traditions and institutions?

- What are the key institutional reforms that are needed to facilitate the development of part-time farming in China?

Jussaume (1991:xiv) notes that, '[a] great deal about part-time farming remains unknown to the scientific community'. This is especially true for China. This fact encourages an increase in research attention on the trends and development of part-time farming. This is an issue that China will have to face as it will affect China's long-term sustainable economic development. 


\section{Part-time farming trends in China}

\section{Appendix 10.1}

\section{Table A10.1 Per capita rural income at the provincial, city/county and}

village level, 1997

\begin{tabular}{|c|c|c|c|}
\hline Province & City/county & Village & Brief description of the region \\
\hline \multirow{2}{*}{$\begin{array}{l}\text { Hubei } \\
(¥ 2,102)\end{array}$} & $\begin{array}{l}\text { Hanyang } \\
(¥ 3,189)\end{array}$ & $\begin{array}{l}\text { Village } 1 \\
(¥ 3,304)\end{array}$ & $\begin{array}{l}\text { A relatively developed region } \\
\text { within the province with good } \\
\text { transportation }\end{array}$ \\
\hline & $\begin{array}{l}\text { Hanchuan } \\
(¥ 2,424) \\
\text { Changyang } \\
(¥ 1,636)\end{array}$ & $\begin{array}{l}\text { Village } 2 \\
(¥ 2,938) \\
\text { Village } 3 \\
(¥ 1,784)\end{array}$ & $\begin{array}{l}\text { Similar to Hanyang but } \\
\text { slightly less developed } \\
\text { A hilly area with a less developed economy } \\
\text { and market }\end{array}$ \\
\hline $\begin{array}{l}\text { Guangdong } \\
(¥ 3,468)\end{array}$ & $\begin{array}{l}\text { Dongguan } \\
\text { (¥5,021) } \\
\text { Dianbai } \\
\text { (n.a.) } \\
\text { Wuchuan } \\
\text { (n.a.) }\end{array}$ & $\begin{array}{l}\text { Village } 1 \\
\text { ( } ¥ 10,667) \\
\text { Village } 2 \\
\text { (¥2,411) } \\
\text { Village } 3 \\
\text { ( } ¥ 2,948)\end{array}$ & $\begin{array}{l}\text { Highly industrialised area close to } \\
\text { Guangzhou and Hong Kong } \\
\text { Relatively less developed area within } \\
\text { Guangdong province } \\
\text { Similar to Dianbai but in a coastal area }\end{array}$ \\
\hline $\begin{array}{l}\text { Yunnan } \\
(¥ 1,375)\end{array}$ & $\begin{array}{l}\text { Yuxi } \\
(¥ 3,248) \\
\text { Lanchang } \\
\text { (¥578) } \\
\text { Dali } \\
(¥ 2,279)\end{array}$ & $\begin{array}{l}\text { Village } 1 \\
(¥ 6,442) \\
\text { Village } 2 \\
\text { ( } ¥ 719) \\
\text { Village } 3 \\
(¥ 2,114)\end{array}$ & $\begin{array}{l}\text { A wealthier area with much injection from a } \\
\text { highly developed tobacco industry } \\
\text { Very remote and mountainous area, one of } \\
\text { the poorest regions } \\
\text { Very remote and mountainous area, one of } \\
\text { the poorer regions with tourist resources }\end{array}$ \\
\hline
\end{tabular}

Notes: National level per capita income of rural population in 1997 was $¥ 2090$. At the city/ county level, there are no systematic data available for per capita income of rural population. Village level per capita income was calculated from the village sample survey data.

Sources: Ministry of Agriculture, 1997. China's Agricultural Statistics, China Agricultural Press, Beijing:433; Hubei Statistical Bureau, 1999. Hubei Rural Statistical Yearbook 1999, China Statistical Press, Beijing:391-92; Yunnan Statistical Bureau, 1998. Yunnan Statistical Yearbook 1998, China Statistical Press, Beijing:489-90; State Statistical Bureau, 1998. China Statistical Yearbook, China Statistical Press, Beijing:346. 
Table A10.2 Ratio of per labour-day income between non-farming and farming employment

\begin{tabular}{|c|c|c|c|c|c|c|c|c|c|}
\hline \multirow[b]{2}{*}{ Year } & \multicolumn{3}{|c|}{ Hubei } & \multicolumn{3}{|c|}{ Guangdong } & \multicolumn{3}{|c|}{ Yunnan } \\
\hline & Vil 1 & Vil 2 & Vil 3 & Vill 1 & Vil 2 & Vill 3 & Vil1 & Vil 2 & Vil 3 \\
\hline \multicolumn{10}{|c|}{ Per labour-day income from farming employment (yuan) } \\
\hline $\begin{array}{l}1986 \\
1987 \\
1988 \\
1989 \\
1990 \\
1991 \\
1993 \\
1995 \\
1996 \\
1997\end{array}$ & $\begin{array}{r}5 \\
6 \\
7 \\
8 \\
7 \\
6 \\
7 \\
19 \\
14 \\
18\end{array}$ & $\begin{array}{r}5 \\
6 \\
6 \\
7 \\
8 \\
7 \\
8 \\
15 \\
14 \\
13\end{array}$ & $\begin{array}{l}3 \\
3 \\
3 \\
3 \\
4 \\
3 \\
5 \\
7 \\
6 \\
8\end{array}$ & $\begin{array}{r}5 \\
6 \\
9 \\
7 \\
15 \\
15 \\
13 \\
70 \\
66 \\
44\end{array}$ & $\begin{array}{r}4 \\
5 \\
7 \\
10 \\
10 \\
10 \\
17 \\
18 \\
16 \\
14\end{array}$ & $\begin{array}{r}7 \\
6 \\
8 \\
9 \\
8 \\
7 \\
11 \\
18 \\
18 \\
14\end{array}$ & $\begin{array}{r}2 \\
5 \\
8 \\
10 \\
11 \\
10 \\
9 \\
16 \\
22 \\
16\end{array}$ & $\begin{array}{l}1 \\
1 \\
1 \\
2 \\
2 \\
2 \\
3 \\
5 \\
4 \\
4\end{array}$ & $\begin{array}{l}2 \\
3 \\
3 \\
2 \\
3 \\
3 \\
4 \\
8 \\
8 \\
9\end{array}$ \\
\hline
\end{tabular}

Per labour-day income from non-farming employment (yuan)

$\begin{array}{rrrrrrrrrr}1986 & 9 & 5 & 4 & 7 & 18 & 7 & 5 & 3 & 3 \\ 1987 & 14 & 5 & 2 & 7 & 19 & 8 & 7 & 2 & 3 \\ 1988 & 17 & 6 & 6 & 10 & 24 & 8 & 8 & 6 & 8 \\ 1989 & 18 & 7 & 7 & 18 & 15 & 8 & 6 & 6 & 6 \\ 1990 & 15 & 7 & 7 & 19 & 16 & 9 & 11 & 5 & 4 \\ 1991 & 12 & 7 & 8 & 28 & 18 & 9 & 17 & 6 & 5 \\ 1993 & 17 & 7 & 7 & 72 & 37 & 24 & 26 & 11 & 6 \\ 1995 & 32 & 17 & 13 & 60 & 49 & 24 & 29 & 8 & 19 \\ 1996 & 32 & 18 & 16 & 66 & 50 & 20 & 40 & 7 & 14 \\ 1997 & 20 & 26 & 13 & 66 & 41 & 21 & 46 & 3 & 19\end{array}$

Ratio of per labour-day income between non-farming and farming employment

$\begin{array}{llllllllll}1986 & 1.8 & 1.0 & 1.5 & 1.4 & 4.3 & 1.1 & 2.3 & 3.3 & 1.5 \\ 1987 & 2.2 & 0.9 & 0.6 & 1.2 & 3.9 & 1.4 & 1.4 & 1.8 & 1.2 \\ 1988 & 2.6 & 1.0 & 2.0 & 1.1 & 3.5 & 1.0 & 1.1 & 4.0 & 3.0 \\ 1989 & 2.3 & 1.0 & 2.3 & 2.6 & 1.5 & 0.9 & 0.6 & 3.0 & 3.0 \\ 1990 & 2.1 & 0.9 & 1.8 & 1.3 & 1.6 & 1.1 & 1.0 & 2.5 & 1.3 \\ 1991 & 2.0 & 1.0 & 2.7 & 1.9 & 1.8 & 1.3 & 1.7 & 3.0 & 1.7 \\ 1993 & 2.4 & 0.9 & 1.4 & 5.5 & 2.2 & 2.2 & 2.9 & 3.7 & 1.5 \\ 1995 & 1.7 & 1.1 & 1.9 & 0.9 & 2.7 & 1.3 & 1.8 & 1.6 & 2.4 \\ 1996 & 2.3 & 1.3 & 2.7 & 1.0 & 3.1 & 1.1 & 1.8 & 1.8 & 1.8 \\ 1997 & 1.1 & 2.0 & 1.6 & 1.5 & 2.9 & 1.5 & 2.9 & 0.8 & 2.1\end{array}$

Source: Calculated from the farm survey data. 


\section{Part-time farming trends in China}

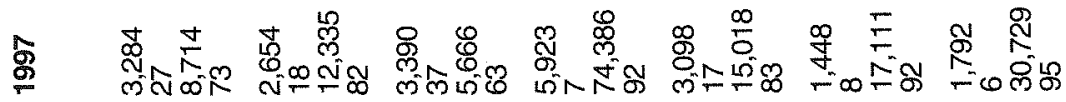

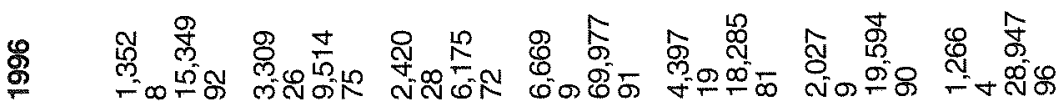

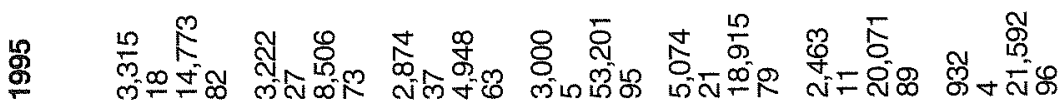

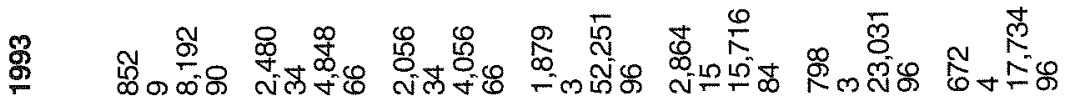

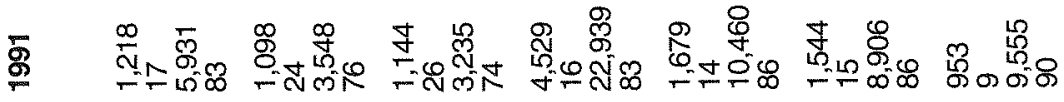

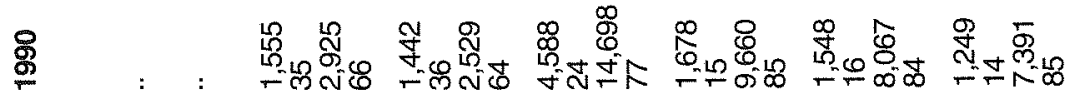

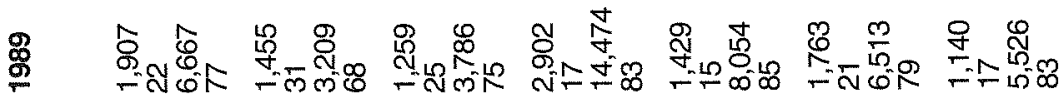

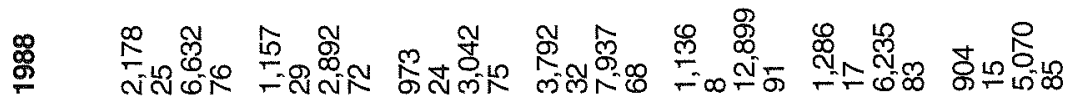

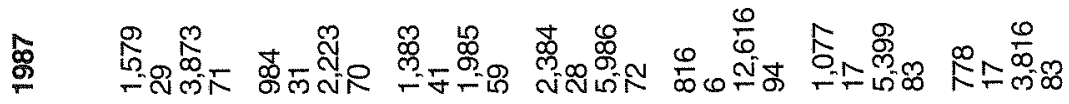

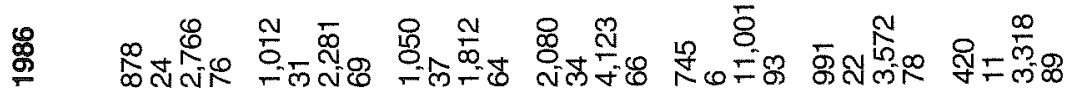

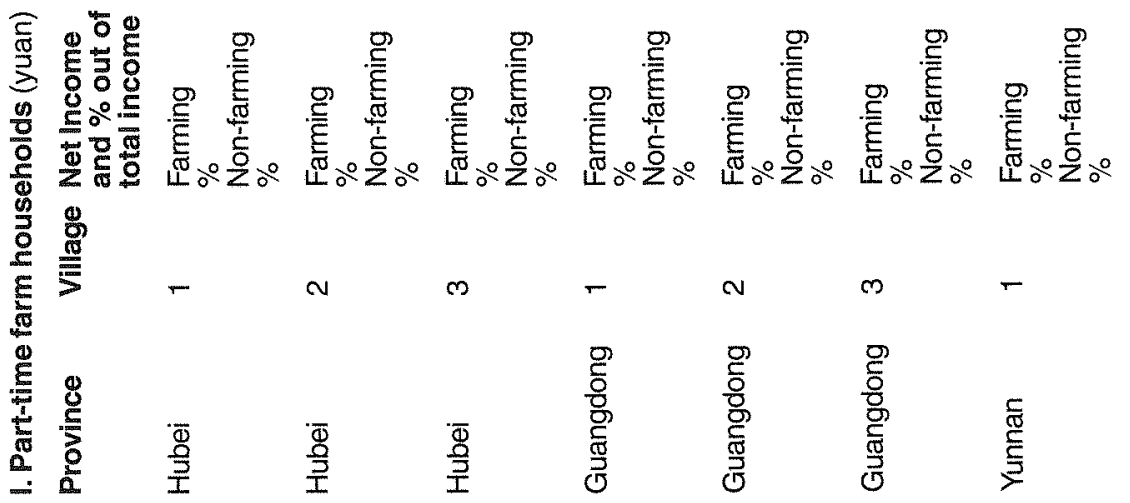




\section{Dilemmas of China's Growth in the Twenty-First Century}

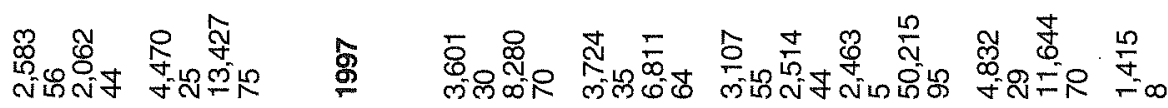

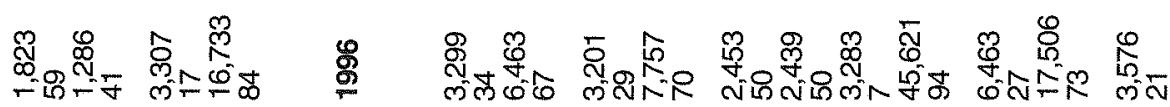

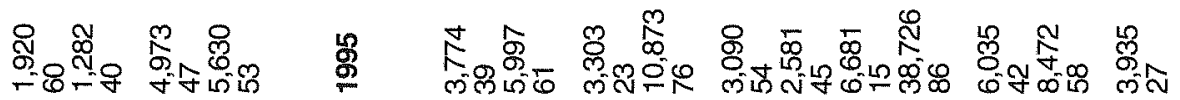

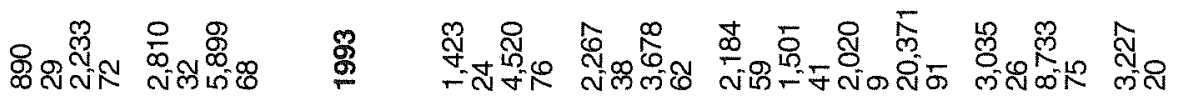

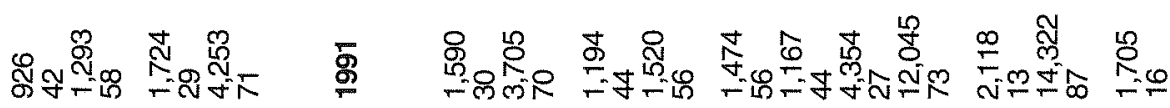

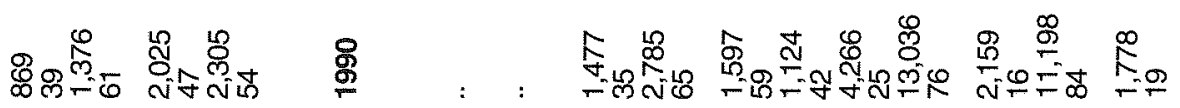

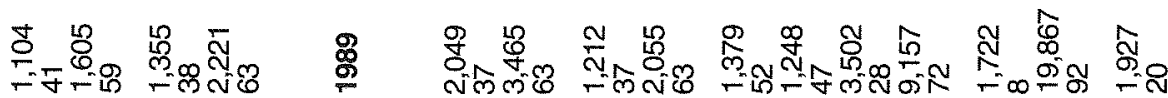

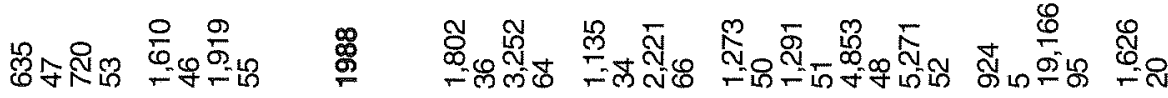

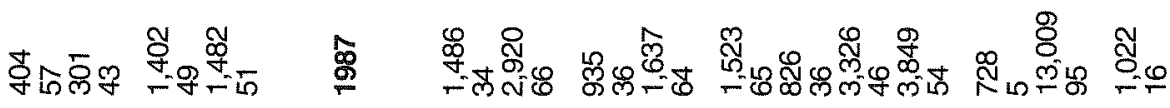

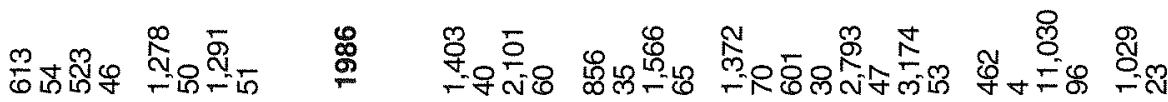

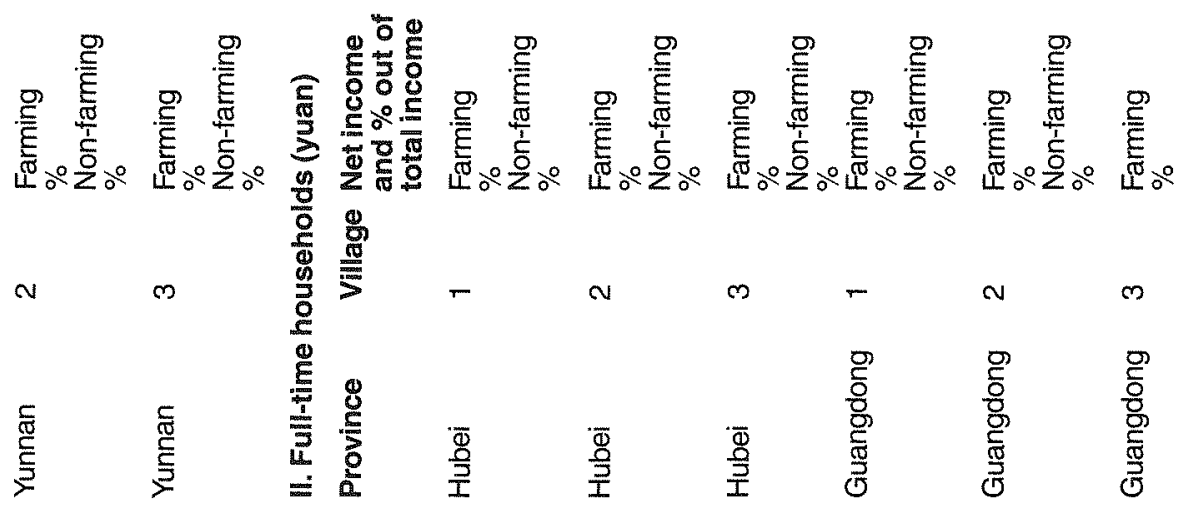


Part-time farming trends in China

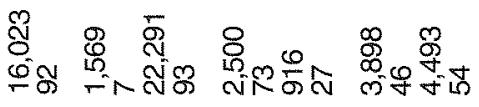

总

宽

品

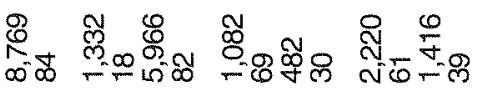

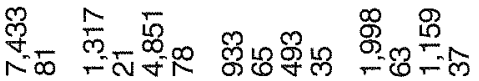

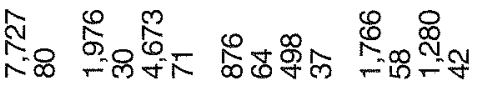

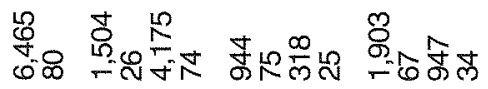

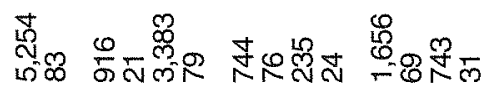

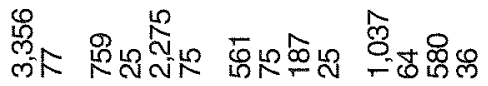

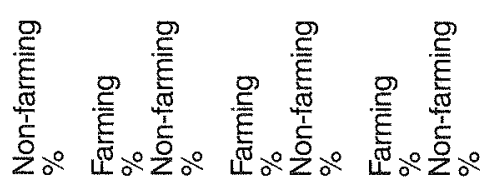

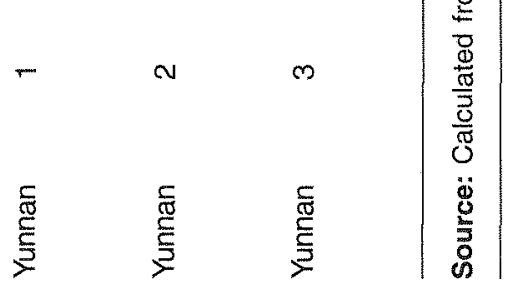




\section{Dilemmas of China's Growth in the Twenty-First Century}

\section{Acknowledgments}

Part of the research work for this study was carried out while Zhang-Yue Zhou was on sabbatical leave at The Department of Agricultural and Resource Economics of The University of California. The authors wish to thank a number of individuals who helped with this study, especially De-Wen Wang of The Ministry of Agriculture in China, Wei-Ming Tian of The China Agricultural University, and Xiao-Hui Zhang of The Research Centre for Rural Economy. We also thank Ji-Hong Li for her assistance in data analysis and Marjorie Wilson for her editorial assistance.

\section{Notes}

1 The discussion on factors affecting part-time farming is partly based on Tian and Shi (1991).

2 For more details about the evolution of the definition of part-time farming, see Institute of Developing Economies (1969).

3 In 1996, one further category was added: no family business operations. Currently, the number of families without any business operations is small. 